\title{
AUTHORITY AND COMMITMENT: \\ Why UNiVersities, Like Legislatures, Are \\ NOT ORGANIZED AS FIRMS
}

\author{
SCOTT E. MASTEN \\ Stephen M. Ross School of Business \\ University of Michigan \\ 701 Tappan St. \\ Ann Arbor, MI 48109-1234 \\ semasten@umich.edu
}

This paper explores the functions and limitations of democratic governance by analyzing the allocation of decision-making authority in colleges and universities. Contrary to the conventional perception that large numbers and heterogeneity of voters and issues undermine the efficiency of democratic decision making, data on the allocation of authority for thirty-one decision areas in 826 US colleges and universities show democratic governance to be more prevalent in larger, "full-service" research universities than in smaller liberal arts colleges and special-curriculum institutions. State- and church-affiliated institutions, meanwhile, tend to be governed more like firms. The results overall are consistent with economic theories of political organization that view democratic governance primarily as a means of enhancing the credibility of commitments rather than as a method of aggregating preferences.

"Educational systems, like governments, apparently can never be rational, never a logical and economical means to a definite end.

Rather must they be always makeshifts."

-J.P. Munroe (1899)

"Never did a dean lack legitimate reasons by which to color his bad faith"

-Machiavelli, The Dean (1513)

This research has benefited from the comments of Donald Alexander, Charles Clotfelter, Keith Crocker, Andrew W. Dick, Ronald Ehrenberg, Michael Gibbs, James Meehan and Steven Maser, as well as from participants at numerous seminars and conferences. I thank Otway Pardee and Father James Thornton for their cooperation and assistance in obtaining the data and its documentation. Gautam Ahuja, Avik Chakrabati, and Carrie Winters provided valuable research assistance. This research is part of a larger project on the governance of higher education, generous support for which has been provided by the Lynde and Harry Bradley Foundation and the University of Michigan Ross School of Business. An earlier version of this paper was circulated under the main title "Commitment and Political Governance." 


\section{INTRODUCTION}

Like firms, colleges and universities offer services for a price and compete with each other in both input and output markets. In governance respects, however, academic institutions often resemble governments more than commercial enterprises, with faculty exercising democratic control over a range of significant decisions. Despite the importance of higher education as an industry, and perennial policy clashes over the appropriate role of faculty in university decision making, differences in the governance of firms and universities-and in the extent of democratic decision making within academic institutions themselveshave received remarkably little systematic attention. What research has been done-mainly by historians and sociologists - has been mostly descriptive or normative. A positive analysis of how colleges and universities allocate authority stands to further our understanding of the organization of academic institutions and may also offer insights into the functions and limitations of democratic decision making in political and commercial entities more generally.

The analysis here draws on recent theories of political governance that view the establishment of credible commitments, as opposed to preference aggregation in the tradition of Arrow (1963), as the principal function of political institutions generally and of democratic governance in particular (see Alt and Schepsle, 1990; Miller, 1997, for overviews). The central premise of this perspective is that, like economic transactions, political bargains aim to create joint surpluses but are subject to reneging or appropriation hazards that can prevent deals from being reached or otherwise result in inefficient outcomes. According to this theory, constitutionally prescribed democratic decision rules enhance confidence in governmental policies relative to autocracy (i) by broadening the interests of the government-democratic governments are less likely than autocratic ones to infringe individual property and political interests to the extent those interests are represented in legislatures (North and Weingast, 1989; McGuire and Olson, 1996) —and (ii) by defining and communicating limits on decision-making authority in ways that help to make those limits self-enforcing (e.g., Hardin, 1989; Weingast, 1993; Kandori, 1992a).

This paper extends this conception of the problem of political organization to academic transactions, beginning with the observation that individuals who interact with or within academic institutions-faculty, administrators, students, alumni, and private and public donors, among others-also face numerous opportunities for mutually advantageous trade and cooperation and that, like their commercial and political counterparts, such transactions often entail promises of future performance or rewards in exchange for current actions and investments. To the 
extent such promises are difficult to secure contractually, governance arrangements that enhance confidence in the performance of academic bargains should reduce the potential for costly conflict and increase the willingness of parties to enter such transactions. Of course, democratic decision making also has its drawbacks, and we should therefore expect the governance of academic institutions to vary with the nature and circumstances of the transactions.

Higher education provides a particularly appealing setting for evaluating theories of democratic governance for several reasons. First and foremost, colleges and universities exhibit a wider range of decision structures than do conventional firms: Whereas the archetypical business firm is run autocratically, with formal authority over the organization's operations concentrated in the owner (or owners' agent), the predominant modes of academic governance-administrator determination, faculty determination, and joint administrator-faculty determination-span the three main categories of political governance-autocracy (monarchy or dictatorship), unified (or parliamentary) democracy, and divided (or presidential) democracy. At the same time, educational institutions, as "producers" in a specific industry, serve a narrower (and analytically more tractable) range of interests and may also be more susceptible to competitive pressures than are nations and legislatures. Combined with the large number of academic institutions, these features offer the prospect of testing theories of political governance that have resisted empirical scrutiny in more conventional political and commercial settings. ${ }^{1}$

I begin the paper with an overview of the commitment, or "gainsfrom-trade" (Shepsle, 1993, p. 349), theory of political governance, followed in Section 3 by a description of the problems of academic exchange as they relate to that theory. In Section 4, I identify a set of factors affecting the trade-off between flexibility and commitment and associate those factors with features of academic institutions. Section 5 describes the data, discusses specification issues, and reports results. Among those results is the finding that-contrary to the conventional wisdom that large numbers and heterogeneity of voters and issues encumber democratic decision making-democratic governance in general, and the number of "veto points" in particular, tends to be greater in larger, "full-service" research universities than in smaller liberal arts colleges and special-curriculum institutions. Extensions and implications

1. Because countries vary greatly in their circumstances and conditions relative to their number, empirical research in political science that has attempted to test theories of political organization has had to rely principally on municipal data. Examples of research analyzing features of municipal government in comparative contractual terms include Frant (1993), Patashnik (1996), and Maser (1998). 
of the analysis for the broader study of political and economic organization are discussed in the final section.

\section{AUTHORITY AND COMMITMENT IN POLITICAL EXCHANGE}

The modern conception of political democracy as a commitment device is an outgrowth of research emphasizing the gains from political trade. ${ }^{2}$ In the relations between a government and its citizens, for instance, both ruler and ruled stand to benefit from private investment stimulated by a "bargain" limiting the wealth that the state can appropriate from its citizens. Similarly, politicians stand to gain from striking deals with each other, as when legislators trade votes in pursuit of the majorities necessary to enact legislation benefiting their respective local constituents (e.g., Buchanan and Tullock, 1962). The existence of mutually beneficial bargains does not guarantee their realization, however. Differences in the timing of actions and the accrual of benefits expose political bargains, just like commercial deals, to the risk of reneging: Without adequate assurances that others will, when the time comes, uphold their end of the bargain, citizens may be reluctant to make investments and legislators to expend the political capital necessary to achieve joint surpluses (North and Weingast, 1989; Weingast and Marshall, 1988).

Though similar in nature to the problem of commitment in commercial settings, two aspects of political exchange ostensibly complicate the task of securing agreements among political actors. First, in contrast to commercial transactions, no independent third party with the power to compel performance exists to whom political transactors can appeal to enforce their agreements. As Weingast $(1993,1995)$ has observed, political transactions entail a fundamental dilemma: Any party powerful enough to enforce promises is also powerful enough to abrogate its own commitments and transgress the interests and well being of others. Contracting - which exploits the coercive power of the state to enforce agreements-is simply not available where the control or use of the state's coercive power is itself at issue. Political bargains must, therefore, be self-enforcing.

Second, "self" enforcement of political bargains often requires collective action. Because the sanctions that an individual can impose on a defecting ruler or fellow legislator are typically small, deterrence

2. The commitment properties of democratic rule were, in fact, at the heart of democratic philosophy dating back at least to Montesquieu, James Madison, and Alexander Hamilton. Recent research, however, has provided new theoretical insights into the mechanisms through which democratic institutions operate. For a discussion of these developments, see Miller and Hammond (1989). 
of political opportunism is likely to require the threat of multilateral actions-mass revolts, protests, boycotts, and the like. Carrying out such actions requires coordination: While the success of an insurrection depends on attracting sufficient participation, the cost to an individual of participating in an unsuccessful action (including the possibility of imprisonment or execution) can be severe. To overcome the private disincentive to participate, would-be insurgents must settle on the definition, and find a way of communicating the occurrence, of an infraction and the appropriate responses thereto.

Constitutions, legislative rules or other widely shared norms or expectations about the allocation of decision authority, according to the theory, serve this coordination function. Although a ruler with sufficient power or support could simply ignore constitutional constraints, a widely accepted set of public rules helps citizens (or legislators) settle on a preferred equilibrium strategy in repeated political games by providing a common standard by which to evaluate state actions (Weingast, 1995, p. 15; see also Hardin, 1989; Kandori, 1992a,b). The fundamental difference between autocracy and democracy, from this perspective, lies in the nature and content of those rules and the expectations they generate about the legitimate exercise of decision-making authority. By leaving executive authority unconstrained, autocracy makes it difficult for citizens to identify and verify — and thus lowers the expected punishment for-governmental opportunism. Democracy, by contrast, offers a simple, relatively verifiable criterion by which to judge the legitimacy of governmental actions, namely, that decisions receive the explicit consent of designated individuals or groups before being implemented. ${ }^{3}$

By defining the set of eligible voters and applicable vote thresholds, constitutions, and bylaws also determine both whose interests are protected and the degree of commitment to the status quo. Other things equal, rules establishing more "veto points" - parties or groups with the power to block a proposal-enhance commitment but, in doing so, also make it more likely that some actions with positive expected net benefits will be delayed or blocked. Thus, simple majority rule, which requires acquiescence by only half of enfranchised voters, affords protection to the majority but leaves minority interests exposed to expropriation by a dominant coalition. A unanimity rule, by contrast, assures that all voters' interests are respected but would also often make change all but impossible to accomplish. Intermediate between unanimity and majority rule in the number of veto points established,

3. For a recent modeling effort along these lines, see Bordignon and Minelli (1998, 2000). The problem of designing constitutional rules is analogous in many ways to that of establishing procedures for adaptation in commercial contracts. For economic analyses viewing contracts as constitutions, see Goldberg (1976) and Crocker and Masten (1991). 
bicameral and presidential governments-which require ratification of proposals by multiple, independently elected bodies-and supermajority requirements represent efforts, within this framework, to strike a balance between the competing demands for flexibility and commitment in political decision making. ${ }^{4}$

\section{ACADEMIC EXChANGE AND Governance}

On its face, the considerations that motivate the use of democratic governance as a commitment device in political settings seem applicable to academic settings as well. First, education systems, like political ones, present numerous opportunities for trade. Although typically portrayed as a source of conflict, the broad range of interests that converge within a university-those of faculty, students, alumni, administrators, and private and public donors, among others-form the basis for mutually beneficial cooperation: To the extent, for instance, that faculty and administrators (or other patrons or "stakeholders") place different relative values on research and service to the institution, a bargain in which, say, administrators compensated faculty for foregone research opportunities with higher salaries, future appointments of desired colleagues, or any number of other things that faculty desire, would leave both parties better off. ${ }^{5}$

Second, the costs and benefits of academic bargains, like their political counterparts, often accrue nonsimultaneously, making them susceptible to reneging and appropriation. The prospect of the other side failing to carry out its end of the bargain would tend to discourage donors wary that their contributions will be redirected away from their intended use, make administrators hesitant to award tenure and raises for fear that faculty will merely reallocate their time to consulting and leisure, and deter faculty from contributing to the teaching and service

4. The tension between commitment and flexibility is apparent in contemporary discussions and analyses of the relative merits of unified and divided democracy, with critics of American-style presidential democracy often complaining that the system's separation of powers produces governmental gridlock, whereas citizens of parliamentary systems disparage unified control of executive and legislative functions as "elected dictatorship." Compare, for example, Sundquist (1986) with Reid (1998), and, for a more general discussion, see Moe and Caldwell (1994). In this framework, oligarchy—rule by a few-would lie between autocracy and majority rule on the commitment-flexibility continuum.

5. A number of empirical studies have compared the goals and preferences of faculty and administrators. See, for example, Gross and Grambsch (1974). Differences in the preferences of faculty, as opposed to between faculty and administrators, are another source of conflict in academic settings (e.g., McKenzie, 1979, 1996). Although the discussion in the text is framed primarily in terms of the divergent preferences of administrators and faculty, the logic applies to disagreements among faculty as well. 
objectives of the institution lest they discover their salaries and tenure prospects lagging those of colleagues who spurned committee work in favor of activities more likely to enhance their value in the academic marketplace. ${ }^{6}$

To be sure, agreements between administrators and faculty (or among faculty), unlike political and legislative bargains, are potentially enforceable in court. In practice, however, the complexity and subtlety of academic responsibilities and the need to accommodate changes in demand and resources severely limit the efficacy of contracting as a means of securing academic bargains. ${ }^{7}$ Consider, for example, the difficulty of writing and enforcing a contract to hire a specific colleague in the future in exchange for some current consideration. The successful completion of such an appointment depends on the salary offered, the other opportunities of the candidate, the research and teaching environment of the institution, and the identity of others on the faculty, along with numerous other intangibles. Given the range of variables involved, an administrator's promise to make a particular hire, or the pledge of one faculty faction to support a future appointment or promotion of a scholar in another faction's specialty, is likely to be easily evaded (or subtly sabotaged) once the first parties' objectives have been achieved. Thus, although contracting is possible in principle, as a practical matter, academic bargains, like political ones, must largely be self-enforcing.

Finally, and most important, deterrence of cheating on academic bargains is likely to require multilateral action. While the sanctions

6. A good illustration of the tension between donor and academic objectives can be found in the controversy surrounding Yale University's return of a \$20 million gift from Lee M. Bass (see, e.g., Mercer, 1995).

7. McKenzie (1996) and Besse (1973, pp. 110-111) provide good descriptions of some of the difficulties of quantifying professorial responsibilities. Milgrom and Roberts (1992, pp. 127-129) use education to illustrate the difficulties of complete contracting. Even if some dimensions of academic transactions (such as salary or course load) are contractible, incentive distortions resulting from the inability to contract over other aspects of performance are likely to make explicit contracting unattractive (see, generally, Holmstrom and Milgrom, 1991, 1994). Finally, Bernheim and Whinston (1998, pp. 902-904) also use faculty employment contracts to motivate their theory of incomplete contracting.

Academic and political transactions are also similar in their general proscription of cash side payments as a means of "settling up." Thus, the exchange of cash for political favors, whether between citizens and politicians or among legislators, is illegal in most societies, whereas trading of votes (logrolling) generally is not. In academic institutions, the tenure system and restrictions on the distribution of surpluses by educational nonprofits-themselves endogenous institutional responses to problems of contracting for education services-place limits on the use of cash to bring about bargains: Allowing administrators to make side payments in exchange for faculty investments-in a "pay-asyou-go" fashion-would counteract the safeguards against arbitrary or vindictive actions afforded by the tenure system and substantially weaken the nondistribution constraint that characterizes not-for-profit organization. See generally, Hansmann (1980), Masten (1995), Carmichael (1988), and McKenzie (1996). 
that a particular faculty member can unilaterally inflict on a defecting administrator or colleagues tend to be few and small, the private costs of participating in a faculty revolt - which might prove an effective deterrent if carried out-are potentially large, in terms of forgone research but also, and perhaps especially, as a result of an administrator's (or majority faction's) ability to target rewards and retaliation selectively. ${ }^{8}$ To make the threat of multilateral action credible and thereby secure the benefits of academic bargains, a means of identifying and coordinating responses to cheating on academic bargains may thus be needed. ${ }^{9}$

As in political contexts, widely shared norms or expectations about the allocation of authority for academic decisions may serve this coordinating function. ${ }^{10}$ First, compared to the deep knowledge needed to determine whether the substance of a bargain has been honored, conformance with rules defining decision rights and requirements is relatively easy to verify. Second, expanding the set of parties with veto authority increases the stability of bargains. In institutions that vest authority exclusively in administrators, a discrete change in policy or practice (such as a change in program emphasis or in the relative weights assigned teaching and research in tenure decisions) requires a change in the priorities or identity of only a single individual; effecting the same policy change under rules requiring the concurrence of a specified majority of enfranchised faculty, by contrast, would necessitate a shift in the overall distribution of faculty preferences or identities sufficient to make the new policy the preferred course of the decisive voter (or voters). By giving those who would be adversely affected by a proposal the potential to block its passage, faculty governance

8. Media accounts, lawsuits, and other sources report allegations of retaliation by administrators using salary, course load and teaching assignments, office space and termination, among other things. In a recent and particularly egregious illustration, a professor was reportedly put under effective "house arrest," required by university administrators to remain in his office and forbidden to leave campus without permission and an escort during regular working hours (Walsh, 2002). More often, retaliation is likely to take more subtle forms such as being passed over for promotions and loss of raises and influence.

9. A famous example of the failure to sustain a collective response to administrator opportunism in American higher education was the turn-of-the-century case of Edward A. Ross at Stanford. At the behest of founder Leland Stanford's widow, Stanford University president David Starr Jordan forced Ross, an economist and secretary of the American Economic Association, to resign for having publicly voiced unpopular positions (on Asian immigration and municipal ownership of public utilities). Although seven prominent Stanford professors quit in protest, and despite widespread condemnation of Stanford's action, plans for a nationwide boycott of Stanford "quickly lost its thrust" as even staunch defenders of academic freedom began accepting appointments to fill the positions opened by the resignations (Veysey, 1965, p. 415).

10. For an interesting account of the effect of norms on academic governance in practice, comparing the universities of Michigan and California-Berkeley, see Hollinger (2001). 
increases confidence in the continuity of existing policies and, thereby, the willingness of faculty to conform their behavior to standards and policies peculiar to a particular institution. By the same token, requiring the assent of faculty and administrators affords administrators (and the interests they represent) protection against faculty overreaching and, to the extent it further contributes to the stability of academic policies, stands to help preserve minority interests among faculty as well. The trade-off-bemoaned by administrators, trustees, and even some faculty-is that, in making it harder to effect adaptations, joint administrator-faculty authority (divided democracy) increases the risk that efficient adjustments will be forestalled. As one critic put it, shared governance "becomes, in effect, governance by multiple veto by campus groups with vested interests [that] can stymie necessary reforms" (de Russy, 1996). ${ }^{11}$

\section{Comparative Analysis}

The theory of political organization outlined above offers a plausible rationale for the existence of democracy in political and academic settings but does not, by itself, account for variations in the incidence and form of democratic governance among either states or schools. Perhaps as important, it also leaves unexplained why democratic governance is not more widely used to address commitment problems in other settings where third-party enforcement is also infeasible or impractical. Agency theorists, for instance, have long noted that an employer's inability to commit not to revise compensation schemes limits its ability to elicit effort and firm-specific investments from employees (e.g., Gibbons, 1987, 1998). In fact, the conditions alleged to motivate democratic governance in political and academic settings could be argued to characterize most traditional employment relations: In the typical firm, (i) the effort and investments employees are willing to make depend on the credibility of promised rewards; (ii) contingent contracting is impractical (and seldom observed); (iii) multiple employees interact with a single employer; and (iv) the sanctions that an individual employee can exact on a reneging employer (other than quitting) are generally few and relatively minor. ${ }^{12}$ Yet the archetypal firm is governed autocratically, with formal authority

11. Although the existence of positive net benefits implies that a set of transfers could, in principle, leave even those directly hurt by a proposal better off, the practical problems of agreeing on and effecting those transfers (think about the difficulty of satisfying a unanimity requirement for hiring in even a moderately sized academic department) will often prevent, or at a minimum substantially delay, their realization.

12. Even the ability to use cash to effect bargains within traditional firms is, as in political and academic situations, circumscribed: "the restriction on the use of money as a means to curry favors and compete for services within the firm" represents a constraint on 
over the organization's operations consolidated in the owner or owners' agent. $^{13}$

There are, of course, good reasons for preferring centralized authority in organizations. Autocrats, unlike executives in pluralist systems who are obliged to obtain the consent of others before taking action, can act unilaterally and decisively in times of crisis or opportunity. In the language of the theory of the firm, hierarchical governance affords executives the authority to respond to changing circumstances in "an adaptive, sequential fashion" (Williamson, 1975, p. 25). Democratic decision making, by contrast, is widely disparaged as slow, cumbersome, and inefficient. Frequent criticisms include policy incoherence; lack of accountability; capture by special, entrenched, or ideological interests; and an inherent propensity to preserve the status quo to the extent of fostering "gridlock."14 Ideally, a positive theory of political and academic organization would yield insights into why democratic governance is not used as a commitment device in traditional business firms as well as explain variations in governance form among states and schools. Toward that end, I first draw on the literatures on political and economic organization to identify a set of factors expected to affect the demand for democracy as a commitment device generally, and then relate those factors to the characteristics of academic institutions. ${ }^{15}$

\subsection{THE DEMAND FOR DEMOCRACY}

As set out in the theory, the commitment value of democracy derives ultimately from a combination of (i) the vulnerability of transactions to reneging (and inadequacy of unilateral reputational and legal sanctions as deterrents thereto), and (ii) difficulty in the evaluation and communication of violations of substantive agreements as a trigger for collective "self-enforcement." Where individuals are protected either by their mobility or, absent that, by consensus on the limits of executive discretion, the flexibility advantages of autocracy are likely to dominate.

the activities of employees that is "so obvious as to elude our recognition" (Holmstrom, 1999, p. 94).

13. The peremptory authority of executives is the property most often associated with internal organization in the theory of the firm. In the words of Milgrom and Roberts, "what most distinguishes any centralized organization is the authority and autonomy of its top decisionmakers or management-that is, their broad rights to intervene in lowerlevel decisions and the relative immunity of their decisions from intervention by others" (Milgrom and Roberts, 1990, p. 79). See, also, Coase (1937), Simon (1951), Grossman and Hart (1986), and Williamson (1975).

14. Compare Schuster et al. (1994, p. 9) and de Russy (1996) (criticizing university governance) with Fiorina (1996, pp. 85-87), Krehbiel (1996, p. 9), and Pfiffner (1991, pp. 4446) (describing the problems of political democracy).

15. I discuss the implications of the analysis for understanding the relative rarity of democratic governance in traditional firms in the conclusion. 
On the one hand, transactors whose investments are not location- (or institution-) specific and who can therefore relocate to a new community (or employer) at low cost have little need for commitment mechanisms (of any type). On the other, communities whose members find it easy to agree on, communicate and verify the occurrence of a substantive transgression will have less need to resort to procedural rules and norms to coordinate collective sanctions. Only where individual mobility is sufficiently limited and collective enforcement ineffective is the commitment value of democratic rules likely to exceed autocracy's administrative economies.

Outside the political and academic spheres, substantial evidence exists that immobility, or "nonredeployability," increases the demand for protective governance structures: Both long-term contracts and vertical integration, for example, are more likely for transactions involving relationship-specific investments. ${ }^{16}$ By extension, differences in "migration" possibilities among communities should lead to a higher value for democratic processes (or other efforts to protect political interests) at the national than municipal level, and in cities than in smaller, more compact "communities" such as, say, apartment complexes. Applied to academic institutions, the logic implies a greater tendency toward democratic governance, and toward forms of democracy more protective of the status quo, in institutions with less mobile faculty, ceteris paribus.

Because the credibility of collective sanctions depends on the ability of individuals to recognize, communicate, and coordinate responses, the prospect of successful collective enforcement of substantive agreements is commonly linked to the homogeneity of community members' perceptions and interests. Discussing the collective enforcement of transactions between medieval traders and their agents, for example, Grief (1993) notes that "[i]f some merchants consider specific actions to constitute 'cheating' while others hold a different opinion, the effectiveness of the collective threat is undermined" (p. 542), and goes on to discuss the role of ethnic and cultural homogeneity in promoting the consensus needed to sustain cooperation. Similarly, Weingast identifies diversity of citizen beliefs and preferences as crucial impediments to effective limits on sovereign power, observing that, where "there is a diversity of preferences over outcomes, ... the nature of citizen views about the appropriate role of the state and what actions constitute a

16. The theoretical argument regarding relationship-specific investments in economic transactions has been most fully laid out in the transaction cost literature, beginning with Williamson $(1975,1985)$ and Klein et al. (1978). The empirical evidence has been reviewed in a number of surveys, including Shelanski and Klein (1995). In political science, mobility has played its most conspicuous role as a prerequisite to Tiebout-style competition among governments (Tiebout, 1956). 
transgression are likely to differ widely,... making it more likely that the game will result in asymmetric equilibria in which the sovereign transgresses the rights of some and retains the support of others" (1995, p. 14). By contrast, "When the state of agreement in society is large, producing something approaching a consensus, a sovereign who attempts to transgress against citizens cannot survive" (id.). Conformity of interests and beliefs can be expected to play a similar role in academic institutions, making the threat of collective retaliation for substantive transgressions more credible among faculty with more similar experiences, interests and perceptions. As heterogeneity of faculty beliefs and preferences increase, so should the demand for voting rules that raise the threshold for altering the status quo. ${ }^{17}$

Finally, firms, colleges, and nations also transact with external parties whose participation and cooperation may depend on the credibility of bargains. Aware that democratic bodies can vote to redirect expenditures, potential investors or donors, for example, may be reluctant to contribute resources to democratically controlled entities. To secure funding from such patrons, members may find it necessary to cede some control over the use of contributions by giving patrons (or their agent) a veto or, as in the case of for-profit corporations and their shareholders, full authority over expenditures and operations. Even in political relations, governments-including nations philosophically predisposed toward democracy such as colonial Britain or the US during the Cold War-have frequently exhibited a preference for dealing with client states ruled by an autocrat-agent that could be more easily controlled or replaced than a democratic government. Presumably, the insecurity of, and hence the value of ceding authority to, external investor-patrons will be larger the greater the disparity between their interests and those of the recipient community's members.

Table I summarizes the pair-wise predictions of the relative efficiency of autocracy and unified and divided democracy based on the preceding discussion, where $\Delta \beta_{i j}=\beta_{i}-\beta_{j}$ represents the predicted effect of the corresponding explanatory variable on the differential efficiency of governance forms $i$ and $j$, and subscripts $a, u$, and $d$ represent autocracy, unified democracy, and divided democracy, respectively.

17. Although simple majority rule protects the interests of enfranchised majorities, it leaves minority interests subject to majority appropriation. Forms of democracy that increase the number of parties with veto authority both expand the range of interests protected and increase the stability of the status quo.

In addition to its direct effect on collective enforcement, heterogeneity also stands to increase the demand for democracy indirectly through its effect on mobility: Given nonconvexities in production (or nonrivalrous consumption), heterogeneity of preferences, abilities and locations implies fewer and less compatible trading partners and, hence, less mobility. 
TABLE I.

\section{SUMMARY OF PAIRWISE GOVERNANCE COST COMPARISONS}

\begin{tabular}{lccc}
\hline & $\begin{array}{c}\text { Unified Democracy } \\
\text { Relative to } \\
\text { Autocracy } \\
\Delta \beta_{u a}\end{array}$ & $\begin{array}{c}\text { Divided Democracy } \\
\text { Relative to } \\
\text { Autocracy } \\
\Delta \beta_{d a}\end{array}$ & $\begin{array}{c}\text { Divided Democracy } \\
\text { Relative to } \\
\text { Unified Democracy } \\
\Delta \beta_{d u}\end{array}$ \\
\hline $\begin{array}{c}\text { Immobility; } \\
\text { heterogeneity }\end{array}$ & $>0$ & $>0$ & $>0$ \\
$\begin{array}{c}\text { Disparity of } \\
\text { external interests }\end{array}$ & $<0$ & $<0$ & $>0$ \\
\hline
\end{tabular}

Greater immobility and heterogeneity of community members is predicted to increase the value of both unified and divided democracy relative to autocracy $\left(\Delta \beta_{u a}, \Delta \beta_{d a}>0\right)$ and of divided democracy relative to unified democracy $\left(\Delta \beta_{d u}>0\right)$, whereas greater disparity between the interests of community members and outside patrons is predicted to favor the allocation of greater authority to an executive serving as agent for those patrons, with $\beta_{a}>\beta_{d}>\beta_{u}$.

\subsection{CHARACTERIZING EDUCATIONAL INSTITUTIONS}

Faculty mobility and the interests and perceptions of faculty and patrons are difficult to measure directly, and what proxies are available tend to be endogenous: Attributes of faculty at a particular institution, for instance, are likely to vary more frequently than-and arguably as a function of-the institution's governance. ${ }^{18}$ Two aspects of academic institutions that tend to be both relatively stable and antecedent to an institution's governance, however, are its function (or "mission") and affiliation. The differences in function that form the basis for classifying institutions as doctorate-granting research universities, liberal arts colleges and specialized institutions such as technological institutes, music schools, and theological seminaries, for example, are largely foundational, as is an institution's status as public, private or religiously affiliated..$^{19}$ To the extent that categories of institutions differ systematically in the relevant

18. McCormick and Meiners (1988), for example, use faculty governance as an explanatory variable in the determination of research productivity.

19. The Carnegie Classification of Institutions of Higher Education, one of the earliest and most widely used classifications schemes, described its purpose as "to identify categories of colleges and universities that would be relatively homogeneous with respect to the functions of the institutions as well as with respect to characteristics of students and faculty members" (Carnegie Commission, 1973, p. v). 
characteristics, corresponding variations in governance form would provide provisional support for the theory. The remainder of this section draws on the existing literature to rank institutions conceptually in terms of the heterogeneity and mobility of faculty and the disparity of patron interests; Section 5.2.1 presents statistical evidence that institutional categories vary significantly in their observable characteristics.

Heterogeneity. Two ways in which institutions differ across categories are (i) the number and breadth of their activities and programs and (ii) the degree of faculty specialization within those programs. Compared to liberal arts colleges devoted principally to undergraduate education or to specialized institutions with a limited subject range, large, "full service" research institutions present more issues and activities over which faculty preferences and attitudes may differ: Research versus teaching; undergraduate versus graduate instruction; liberal arts versus professional or "vocational" training; allocations of institutional resources among disciplines or between theoretical and practical or applied scholarship, and so on. Large, research universities are also able to accommodate greater faculty specialization within programs and departments, creating greater diversity in interests, methods and perspectives and greater difficulty in understanding and evaluating others' contributions. ${ }^{20}$ The effect of these differences suggests the alignment of categories of institutions along a continuum of heterogeneity roughly as depicted in Figure $1 .^{21}$

Mobility. Though less definitive, faculty mobility seems likely to yield a similar ranking of institutions. In theory, the greater specialization of faculty at research institutions and the relatively small number and steeper quality gradient of schools at the upper end of the quality distribution (see, e.g., Masten, 1995) would tend to exacerbate the "matching" problem faced by such faculty: Compared to, say, an instructor at a lower-tier liberal arts college whose teaching skills, though not as highly remunerative, may be equally valued by the relatively large number of similar institutions, faculty at top-tier research institutions (at least below the superstar level) are likely to have a harder time finding equivalent positions at institutions of comparable status and resources. Empirical research provides some support for this conjecture. Ehrenberg et al.'s (1991) summary of research on faculty mobility concludes that "[faculty] mobility tends to be higher at lesser

20. Historically, many of the governance arrangements associated with modern American universities can be traced directly to the rise of research as a function of universities in the late 1800s and early 1900s, and the specialization, heterogeneity and disputes it engendered. See Masten (2006).

21. To the extent that faculty at specialized institutions engage in research as well as instruction, such faculty would tend to exhibit more heterogeneity along this dimension than would faculty at a small liberal arts college oriented exclusively toward teaching. 


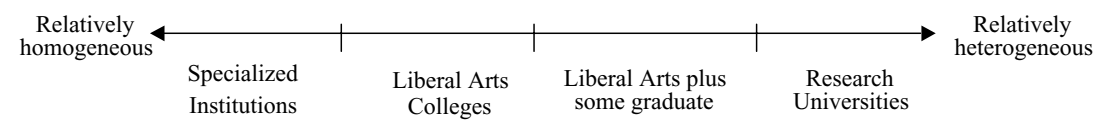

FIGURE 1. ORDERING OF INSTITUTIONS IN RELATION TO HETEROGENEITY

quality institutions" (although their own results appear to contradict some of the earlier studies they cite). Ransom's (1993) finding that, controlling for quality, faculty salaries decline with seniority at a higher rate at "high-quality universities" can also be interpreted as consistent with the existence of lower mobility at higher-tier research institutions, allowing these institutions to appropriate more of the rents accruing to academic transactions.

Patron Interests. In addition to tuition revenue, academic institutions often depend for financial resources on contributions from donors, governments, and religious organizations. Where the interests of the donor and recipient broadly coincide, contributions can be made with relative confidence that they will go to support their intended purpose. Where, in contrast, the interests of those who supply financial resources and those who control their disbursement differ significantly, potential contributors may be deterred by the prospect that their support will be redirected away from its intended use. Although this problem exists for all institutions, its severity will be greater where the objectives of patrons extend beyond the mere production and dissemination of knowledge. Thus, inasmuch as organized religions establish and support colleges and universities to advance nonsecular objectives, those organizations are likely to desire greater control over the administration of the enterprise. By the same token, state-sponsored institutions should be more likely to be run autocratically: The establishment of public universities and colleges in the US originally arose specifically in response to the desire on the part of state legislatures to assure that financial support for higher education served state objectives following the Supreme Court's 1819 decision in the Dartmouth College case that extended constitutional protection to the independence of private universities from state authority (Duryea, 1973, p. 20; see also Goldin and Katz, 1999, pp. 50-52).

\section{EMPIRICAL ANALYSIS}

\subsection{DATA AND METHODS}

The remainder of the paper analyzes patterns in the allocation of decision-making authority using data from a 1970 survey of faculty participation in governance in American colleges and universities 
conducted under the auspices of the American Association of University Professors (Report of the Survey Subcommittee of Committee T, 1971). The sample contains responses from 826 four-year institutions, or roughly half of the 1,665 such institutions in the United States at the time. ${ }^{22}$ Table II shows the distribution of institutions in the sample by category and affiliation. As can be seen from the table, the sample contains a fairly broad mix of institution types.

The survey asked representatives of each institution to identify the locus of decision authority in each of 31 areas of decision making. ${ }^{23}$ Five categories of decision authority were defined as follows: ${ }^{24}$ Decisions or actions over which administrators had unilateral authority were categorized as either Consultation, Discussion, or None, depending on the nature and form of communication between faculty and administrators required to occur before a decision is made. Because faculty lack veto power over decisions in all three of these categories, I have combined these three into a single category, Administrator Determination, for purposes of this study. The label Faculty Determination was given to decisions for which "the faculty of an academic unit or its duly authorized representatives have final legislative or operational authority with respect to policy or action." Finally, Joint Action refers to cases in which actions or policy determinations require "formal agreement by both the faculty and other components of the institution" and are subject to "veto by any component." 25 In the terminology of political systems, administrator determination corresponds to autocracy, faculty determination to unified or parliamentary democracy, and joint action to divided or presidential democracy.

Table III summarizes the distribution of decision authority among the five categories of decision-making practices for each of the

22. US Office of Education, National Center for Educational Statistics (1971). Also in the data, but not analyzed here, is information on 141 junior and community colleges offering two-year degrees.

23. For two-thirds of the institutions (542), answers to the survey were supplied jointly by faculty representatives and administrators. Administrators alone supplied responses at 169 institutions and faculty representatives at 45 institutions. Finally, at 70 institutions, separate responses from faculty and administrators were submitted, bringing the total number of "observations" to 896. Unless otherwise noted, observations for institutions that supplied separate faculty and administrator responses are given weights of one half in the estimations. Not surprisingly, given the relatively small number of institutions with dual responses, such weighting has little effect on the results.

24. See the Appendix for more detailed definitions.

25 . In some cases, authority over a decision area varies among units or faculty within a given institution. In such cases, the survey asked respondents to report the percent of faculty in their institution governed by each governance form. For example, an institution in which $90 \%$ of the faculty are in departments where appointments require joint action and $10 \%$ belong to departments where faculty are appointed unilaterally by administrators would report Faculty Determination: 0; Joint Action: 0.9; and Administrator Determination: 0.1 . 
TABLE II.

NUMBERS OF INSTITUTIONS BY CATEGORY AND AFFiLiATION

\begin{tabular}{lrrcrr}
\hline & Public & Private & Catholic & Other Religious & Total \\
\hline University & 80 & 30 & 14 & 6 & 130 \\
LA plus & 189 & 66 & 43 & 53 & 351 \\
College & 52 & 45 & 58 & 153 & 308 \\
Specialized & 13 & 21 & - & 3 & 37 \\
Total & 334 & 162 & 115 & 215 & 826 \\
\hline
\end{tabular}

thirty-one decision types covered by the survey. As seen in the table, governance varies considerably across decision types. Faculties are, for example, much more likely on average to have formal decision-making authority (faculty determination or joint action) on issues pertaining to academic operation and policy (decisions 6-8) than on financial issues and administrative appointments (decisions 14-20). In addition, the table shows considerable variation in authority within decision types, suggesting that decision-making authority varies across institutions as well as among decision areas. It is this cross-institutional variation that is the focus of this paper. ${ }^{26}$

For estimation purposes, I treat governance structure as the outcome of a discrete choice problem in which governance form is selected as a function of institutional attributes and decision type. Because the allocation of decision authority is not uniform across decision areas within a given institution-faculty at a single institution may have exclusive authority over some decisions, joint authority over others, and no authority over the rest-institutions do not fall neatly into a single governance category but rather differ in the degree to which decisions are made autocratically versus democratically. I deal with this by treating the sample as panel data and correcting for institution- and decision-specific effects. ${ }^{27}$

26. The analysis of variations in the allocation of decision authority across decisions within institutions is the subject of work in progress.

27. More specifically, I treat the governance form for each decision type, $t$, in each institution, $i$, as the unit of observation and divide the explanatory variables into four components as follows:

$Z_{i t}=$ a vector of observable institutional attributes;

$\varphi_{i}=$ unmeasured characteristics of institutions that have common effects across decision types;

$\mu_{t}=$ unmeasured aspects of decision types that have common effects across institutions; and

$\varepsilon_{i t},=$ an error specific to each observation. 


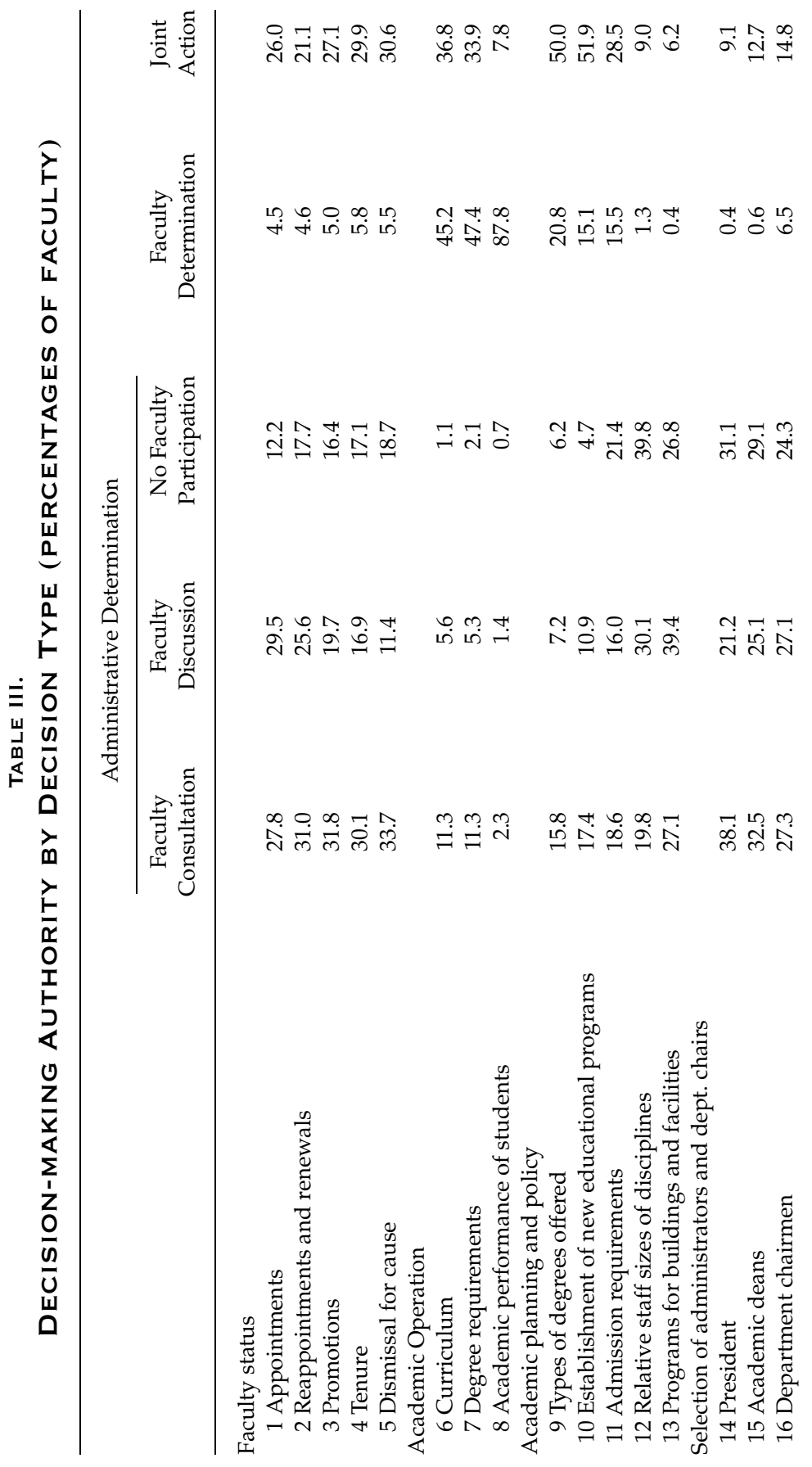




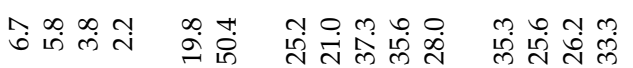

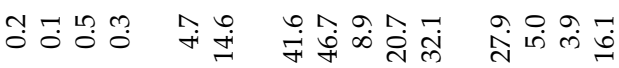

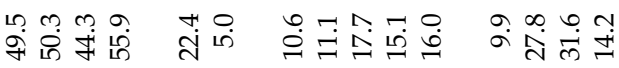

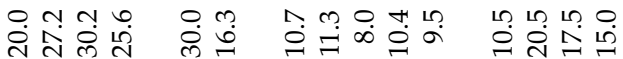

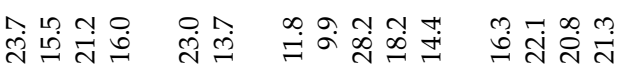

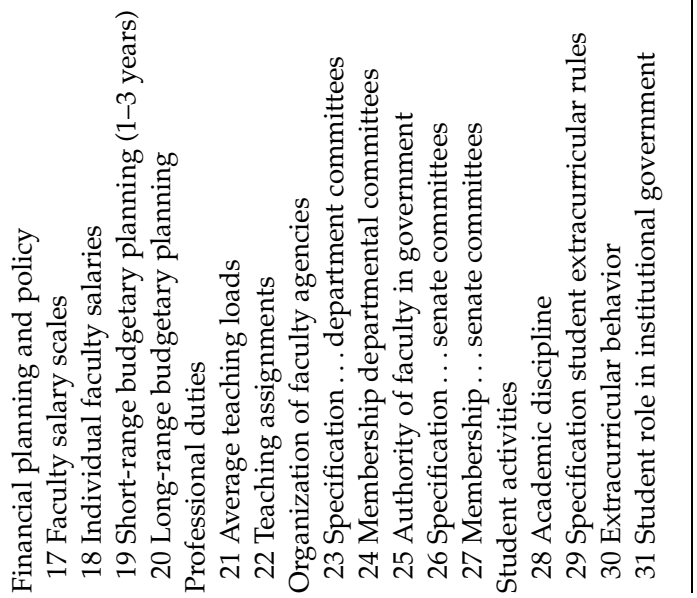


Because the focus of this study is on variations in governance form across institutions rather than across decision types, unobserved decision attributes are treated as fixed effects. An advantage of this specification (over, say, measuring governance as an average across all decision types) is that treating each decision separately and including decision-type fixed effects allows for differences in the variance of the dependent variable among decision areas and permits the estimated marginal effects of institutional attributes on governance form to vary across decisions.

\subsection{ESTIMATIONS AND RESUlts}

The empirical analysis is conducted in three stages. In Section 5.2.1, I provide some background evidence supporting the existence of systematic differences among institutional categories. Section 5.2.2 reports results on the binomial choice between autocratic and democratic governance treating unified (faculty determination) and divided democracy (joint action) as a single category. Multinomial estimates of the choice among all three governance categories are the subject of Section 5.2.3.

\subsubsection{INSTITUTIONAL CHARACTERISTICS}

For evidence on whether institutions in the sample differ significantly in their characteristics, I examine whether various measurable attributes of the institutions vary systematically across institutional categories. Definitions and descriptive statistics for the variables used in the estimations are contained in Table IV. Panel A of the table provides definitions for the basic category and affiliation indicators and their sample means; panel B contains definitions and descriptive statistics for four institutional attributes: student selectivity, research prominence, institution size, and faculty salaries. ${ }^{28}$

Table $\mathrm{V}$ reports the results of regressions relating each of the institutional attributes in panel $\mathrm{B}$ to the institutional categories and affiliation variables. (Columns (1)-(3) are estimated using OLS and column (4) as ordered probit.) The results show significant differences in the characteristics of institutions between most categories. Not

28. Data sources are listed in footnotes to the table. Wherever possible, information from multiple sources was used to check the reliability and accuracy of the AAUP survey data. This and various other diagnostics identified several incorrectly coded data points in the data. In all cases, the most reliable data source was used. In cases where major discrepancies could not be resolved, the observation was eliminated from the sample. The most significant and problematic cases were three instances in which the identity of the institution systematically diverged from information provided. In two cases the observations were omitted (University of Illinois Medical Complex and Rutgers University Camden Campus). The third case involved the institution labeled as University of California Entire Campus, which was determined to be the University of California at Berkeley. This observation was retained in the data. 
TABLE IV.

VARIABLE DEFINITIONS AND DESCRIPTIVE STATISTICS

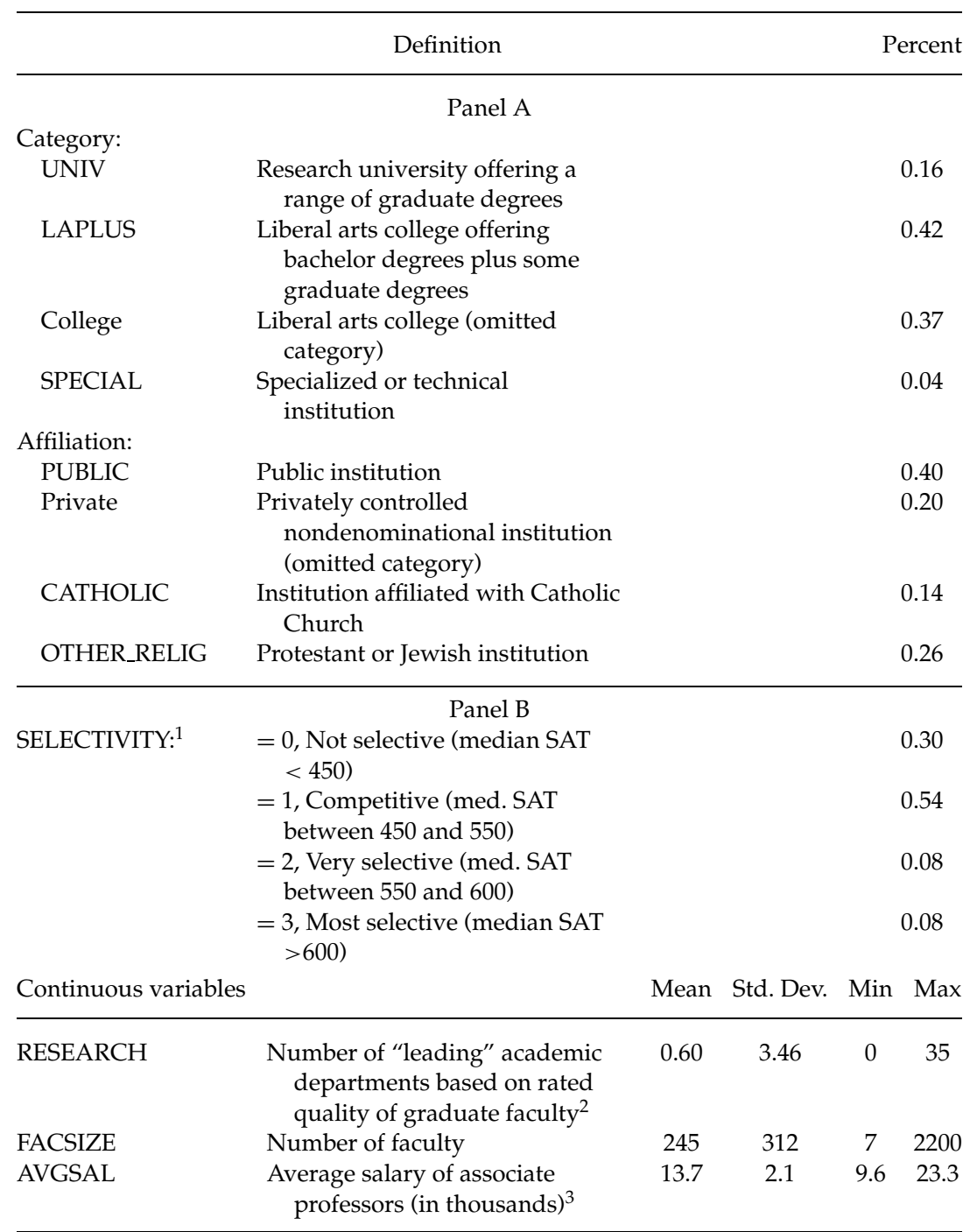

${ }^{1}$ Source: Barron's Profiles of American Colleges, 1970, pp. xix-xxvi.

${ }^{2}$ Source: K.D. Roose and C.J. Anderson, A Rating of Graduate Programs. Washington, DC: American Council on Education. 1970.

${ }^{3}$ Source: AAUP Bulletin, Summer 1971, pp. 247-285. To abstract from the effects of the composition of faculty rank on average salary, average salary figures for association professors are used. The use of associate professor salaries also permits a larger sample size in that the number of associate professors is more likely to exceed the reporting threshold of five individuals. Results using average salary of all faculty are comparable. 
TABLE V.

INSTITUTIONAL ATTRIBUtES

\begin{tabular}{lcccc}
\hline & $(1)$ & $(2)$ & $(3)$ & $(4)$ \\
& RESEARCH & FACSIZE/100 & AVGSAL & SELECTIVITY \\
\hline UNIV & 3.468 & 5.446 & 3.188 & 1.051 \\
& $(9.44)$ & $(22.54)$ & $(13.43)$ & $(7.85)$ \\
LAPLUS & -0.080 & 0.737 & 1.195 & 0.593 \\
& $(-0.29)$ & $(4.05)$ & $(6.20)$ & $(5.89)$ \\
SPECIAL & 0.006 & 0.319 & 2.492 & 0.261 \\
& $(0.01)$ & $(0.82)$ & $(5.77)$ & $(1.26)$ \\
PUBLIC & -0.499 & 1.724 & -1.002 & -1.353 \\
& $(-1.59)$ & $(8.33)$ & $(-5.00)$ & $(-11.58)$ \\
CATHOLIC & -0.975 & -0.438 & -1.491 & -0.437 \\
& $(-2.42)$ & $(-1.65)$ & $(-5.41)$ & $(-3.08)$ \\
OTHER_RELIG & -0.683 & -0.027 & -0.545 & -0.395 \\
& $(-1.91)$ & $(-0.12)$ & $(-2.24)$ & $(-3.15)$ \\
Constant & 0.606 & 0.614 & 13.107 & - \\
& $(1.90)$ & $(2.92)$ & $(60.51)$ & \\
$N$ & 823 & 823 & 592 & 823 \\
Test statistic ${ }^{\mathrm{a}}$ & 24.0 & 158.6 & 43.4 & 184.2 \\
Goodness of fit ${ }^{\mathrm{b}}$ & 0.15 & 0.54 & 0.30 & 0.10 \\
\hline
\end{tabular}

$t$-statistics in parentheses.

${ }^{a} F$ reported in columns (1)-(3), $\chi^{2}$ in column (4).

${ }^{\mathrm{b}} R^{2}$ reported in columns (1)-(3); Pseudo $R^{2}$ in column (4).

surprisingly, universities are significantly more likely than other institutions to have top-ranked research programs. Also as expected, research universities tend to be larger, have the highest paid faculty, and attract the best students; while "liberal-arts-plus" institutions are intermediate between universities and liberal arts colleges (the omitted category) in each of these dimensions. Finally, specialized institutions do not differ significantly from liberal arts colleges in size, research prominence, or selectivity. In terms of faculty compensation, however, specialized institutions appear, on average, to be more like universities than liberal arts colleges; even though specialized institutions may have a narrower disciplinary breadth than liberal arts colleges, faculty at specialized institutions may resemble more their counterparts in departments of research universities than liberal arts professors in terms of research orientation and faculty specialization within the institution's disciplinary focus. Although the available variables do not measure heterogeneity and mobility directly, the results do provide evidence that institutions in different categories do, on average, differ significantly in their observable attributes and that those differences generally "order" as hypothesized. 
TABLE VI.

Binomial PRoBit Estimation of FACULTY GOVERNANCE

\begin{tabular}{|c|c|c|c|c|}
\hline & \multicolumn{2}{|c|}{ Uncorrected Estimates } & \multirow{2}{*}{$\begin{array}{l}\text { Random Effects } \\
\text { Binary } \\
\text { (3) }\end{array}$} & \multirow{2}{*}{$\begin{array}{c}\text { Robust } \\
\text { Standard Errors } \\
\text { (4) }\end{array}$} \\
\hline & (1) & $\begin{array}{c}\text { Proportions } \\
\text { (2) }\end{array}$ & & \\
\hline UNIV & $\begin{array}{c}0.279 \\
(9.79)\end{array}$ & $\begin{array}{c}0.291 \\
(9.93)\end{array}$ & $\begin{array}{l}0.445 \\
(7.00)\end{array}$ & $\begin{array}{r}0.291 \\
(3.80)\end{array}$ \\
\hline LAPLUS & $\begin{array}{c}0.092 \\
(4.27)\end{array}$ & $\begin{array}{c}0.099 \\
(4.50)\end{array}$ & $\begin{array}{c}0.185 \\
(3.76)\end{array}$ & $\begin{array}{c}0.099 \\
(1.78)\end{array}$ \\
\hline SPECIAL & $\begin{array}{l}-0.322 \\
(-6.78)\end{array}$ & $\begin{array}{l}-0.350 \\
(-7.19)\end{array}$ & $\begin{array}{l}-0.233 \\
(-2.38)\end{array}$ & $\begin{array}{l}-0.350 \\
(-2.82)\end{array}$ \\
\hline PUBLIC & $\begin{array}{r}-0.350 \\
(-14.19)\end{array}$ & $\begin{array}{r}-0.380 \\
(-15.07)\end{array}$ & $\begin{array}{l}-0.345 \\
(-6.25)\end{array}$ & $\begin{array}{l}-0.380 \\
(-5.94)\end{array}$ \\
\hline CATHOLIC & $\begin{array}{l}-0.262 \\
(-8.40)\end{array}$ & $\begin{array}{l}-0.285 \\
(-8.93)\end{array}$ & $\begin{array}{l}-0.228 \\
(-3.36)\end{array}$ & $\begin{array}{l}-0.285 \\
(-3.30)\end{array}$ \\
\hline OTHER_RELIG & $\begin{array}{l}-0.012 \\
(-0.44)\end{array}$ & $\begin{array}{l}-0.019 \\
(-0.67)\end{array}$ & $\begin{array}{c}0.164 \\
(2.72)\end{array}$ & $\begin{array}{l}-0.019 \\
(-0.27)\end{array}$ \\
\hline Rho & & & $\begin{array}{r}0.380 \\
(27.79)\end{array}$ & \\
\hline$N$ & 27,159 & 26,570 & 26,570 & 26,570 \\
\hline$L$ & $-13,651.44$ & $-13,022.17$ & $-11,008.55$ & $-13,022.17$ \\
\hline$L_{R}$ & $-13,854.06$ & $-13,244.07$ & $-11,047.70$ & $-13,244.07$ \\
\hline$\chi^{2}$ & 405.24 & 443.8 & 78.3 & 443.80 \\
\hline
\end{tabular}

$t$-statistics in parentheses.

$N$ is number of observations.

$L$ is the log likelihood value.

$L_{R}$ is the restricted log likelihood value (coefficients restricted to one).

Decision-specific fixed effects included but not reported.

\subsubsection{BINOMIAL ANALYSIS}

In this section, I report results on the incidence of faculty veto (whether through faculty determination or joint action) as a function of institutional category and affiliation. Table VI contains estimated coefficients and $t$-statistics for four specifications of the binary choice model. (Decision-specific fixed effects are included but not reported in all models in the paper.) Columns (1) and (2) report probit results in which the observations in the sample are treated as statistically independent (i.e., institution-specific errors, $\varphi_{i}$, are assumed to be uncorrelated). Because governance arrangements can differ among faculty for a given issue within a given institution, the survey data report the proportion of faculty within an institution covered by each governance alternative. For the results in column (1), this proportion was treated as a "grouped" response (see, e.g., Greene, 1995, p. 413). The estimation yielding the results in column (2) differed from that in column (1) only in that the dependent variable was converted to binary form by setting the 
dependent variable to equal one if the reported proportion of decisions governed democratically is greater than 0.5 and zero otherwise. ${ }^{29}$

Because unobserved attributes of institutions may have common effects on the choice of governance form for different decisions, the assumption of independent institution-specific errors is likely to be invalid. To allow for this possibility, columns (3) and (4) report results from estimations using two different methods to correct for the nonindependence of the error terms: For the results in (3), institution-specific errors, $\phi_{i}$ are treated as random effects, whereas in column (4), reported $t$-statistics are calculated using robust (Huber/White/sandwich) standard errors clustered on the identify of the institution. ${ }^{30}$

The results are fairly robust across specifications. Faculties are more likely to participate in (have veto authority over) decisions in universities and, to a lesser extent, in liberal arts institutions offering some graduate degrees (LAPLUS) than in liberal arts colleges (the omitted category), whereas decisions at specialized institutions are significantly more likely to be made autocratically. Hence, the ordering of the main institutional categories-universities, liberal arts plus, colleges, and specialized institutions-is consistent with the main prediction of the commitment theory. The results also show that democratic governance is less prevalent at public and Catholic institutions than at private ones, consistent with these institutions' association with a distinct external patron. The same does not appear to be true, however, for other religious (Protestant and two Jewish) institutions, which either differ insignificantly or are somewhat less likely (in the random effects specification) than private institutions to use administrator determination. ${ }^{31}$ Finally, although the significance of the coefficients generally falls, as expected, following correction of the standard errors for nonindependence, in all but one case (the coefficient on LAPLUS in column (4) is significant only at the 0.10 level), the significance of the coefficients remains well above conventional levels.

\subsubsection{Multinomial ANALYSis}

The binomial estimates above reveal variation in the incidence of democratic governance across institution types consistent with its

29. The dependent variable takes a value of zero or one in approximately $85 \%(22,979)$ of the observations. In the remaining 15\% (4,180 observations), the dependent variable is a proper fraction. Estimating the model defining the dependent variable as one for values greater than 0.9 or by dropping observations for which the reported proportion is strictly between zero and one does not affect the qualitative results.

30. This method assumes independence between clusters but allows, and corrects for, non-independence of errors within clusters. For a discussion and references, see Stata Corp., User's Guide (1999, pp. 231-252).

31. The greater reliance on administrator determination in Catholic than other religious institutions is consistent with the more centralized and hierarchical structure of Catholicism relative to most Protestant denominations. See, for example, Allen (1995). 
hypothesized commitment function. The theory also, however, predicts a preference for joint action over faculty determination as faculty heterogeneity and immobility increase $\left(\Delta \beta_{d u}>0\right)$. Table VII reports the results of the multinomial logit analysis of the choice among administrator determination (autocracy), faculty determination (unified democracy), and joint action (divided democracy). (Again, decision-specific fixed effects are included but not reported.) For the results in columns (1)-(5), the dependent variable is the proportion of faculty at each institution covered by each governance mode (i.e., the responses are treated as "grouped"). The figures in columns (1) and (2) are the estimated coefficients (and associated $t$-statistics), whereas the figures in columns (3)-(5) are the marginal probabilities corresponding to those estimates. As was the case with the grouped binomial estimates in the preceding section, the standard errors used to compute the $t$-statistics in columns (1)-(5) have not been corrected for institution-specific error correlations. To facilitate correction for within-institution correlation in errors, I again transformed the proportions to discrete values. As in column (4) of Table $\mathrm{VI}, t$-statistics in columns (6) and (7) are calculated using robust standard errors clustered on institutions.

The coefficients in columns (1) and (6) show the estimated effects of institution type and affiliation on the propensity to use joint action relative to administrator determination. The estimated coefficients are again similar in the two specifications despite the transformation of the dependent variable and resulting change in sample size. Relaxation of the independence assumption also reduces the absolute value of the $t$-statistics but, as before, the coefficients generally remain significant at conventional levels. Consistent with the commitment theory, heterogeneity increases the attractiveness of divided democracy (joint action) relative to autocracy (administrator determination): Compared to liberal arts colleges (the omitted category), universities and, to a smaller extent, liberal arts colleges offering some graduate degrees (LAPLUS) are more likely, and specialized institutions less likely, to adopt joint action over administrator determination. The results also indicate, as predicted, that public and Catholic institutions are significantly more likely than private institutions to use administrator determination relative to joint action. As before, other religious-affiliated institutions do not significantly differ from their private counterparts in their preference for democratic versus autocratic governance. The marginal probabilities (see columns (3) and (5)) reveal the same patterns; the probability of administrator determination is lower, and that of joint action higher, at more heterogeneous institutions and at private than at public or Catholic-affiliated institutions.

Columns (2) and (7) report the analogous coefficients for faculty determination relative to joint action. As expected, public and Catholic 


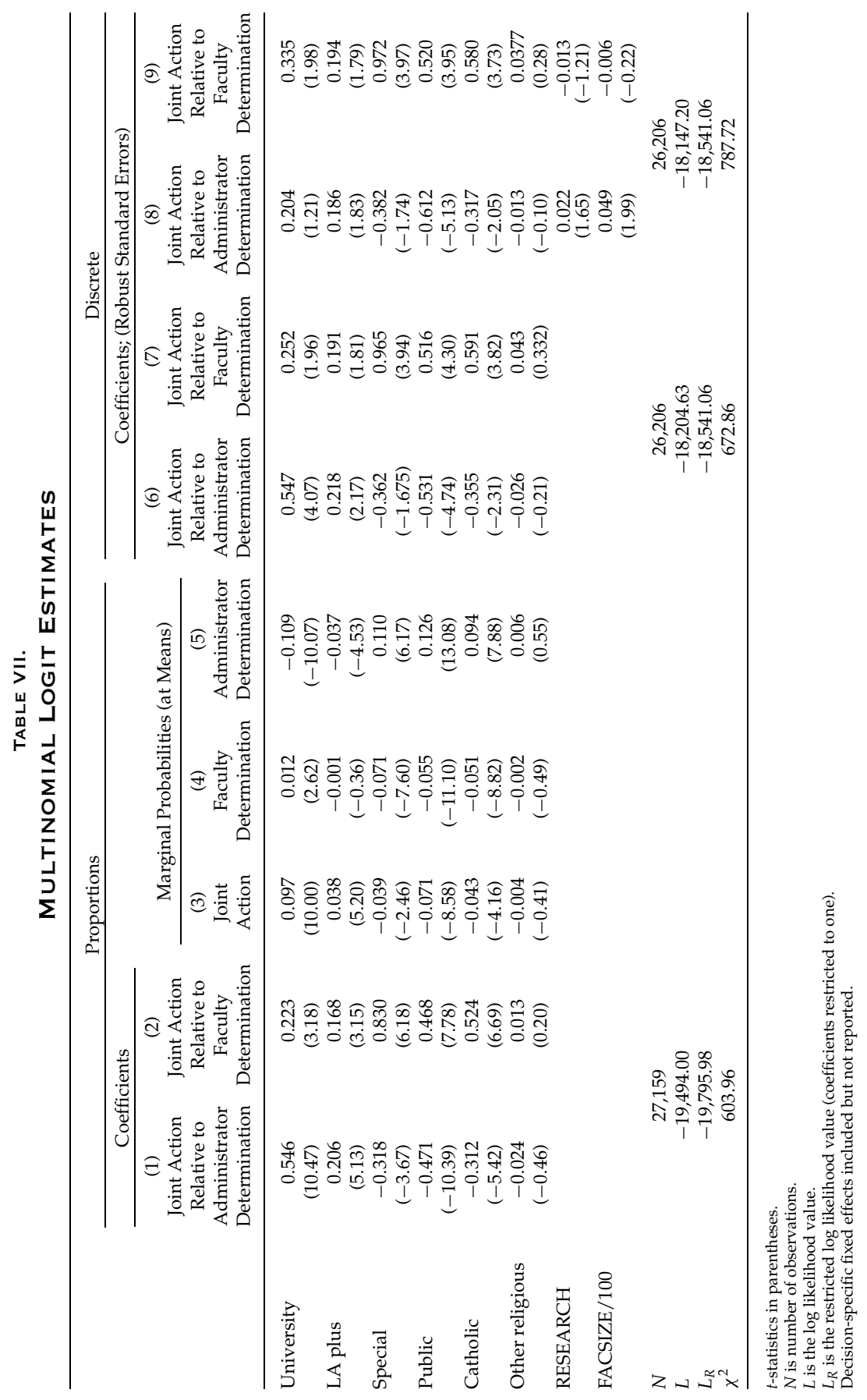


TABLE VIII.

ESTIMATEd PROBABilities of Authority for TENURE DECISIONS (BASED ON ESTIMATES IN TABLE VI, COLUMNS ( 1 ) AND (2))

\begin{tabular}{lcccc}
\hline & Public & Catholic & Other Religious & Private \\
\hline Specialized & $\mathbf{0 . 8 1}$ & $\mathbf{0 . 7 8}$ & $\mathbf{0 . 7 6}$ & $\mathbf{0 . 7 1}$ \\
& 0.01 & 0.01 & 0.02 & 0.03 \\
College & 0.18 & 0.20 & 0.21 & 0.26 \\
& $\mathbf{0 . 7 4}$ & $\mathbf{0 . 7 0}$ & $\mathbf{0 . 6 2}$ & $\mathbf{0 . 6 1}$ \\
& 0.04 & 0.04 & 0.08 & 0.08 \\
LA plus & 0.23 & 0.25 & 0.30 & 0.30 \\
& $\mathbf{0 . 7 0}$ & $\mathbf{0 . 6 7}$ & $\mathbf{0 . 5 8}$ & $\mathbf{0 . 5 7}$ \\
University & 0.04 & 0.04 & 0.08 & 0.08 \\
& 0.26 & 0.29 & 0.34 & 0.35 \\
& $\mathbf{0 . 6 2}$ & $\mathbf{0 . 5 9}$ & $\mathbf{0 . 5 0}$ & $\mathbf{0 . 4 9}$ \\
& 0.05 & 0.05 & 0.09 & 0.09 \\
& 0.33 & 0.37 & 0.41 & 0.42 \\
\hline
\end{tabular}

Notes: Bold: Administrator Determination; Plain: Faculty Determination; Italics: Joint Action.

(albeit not other religious) institutions are less likely than private ones to give faculty exclusive authority over decisions. Faculties also are less likely to have exclusive authority, as opposed to just veto authority, at universities and, somewhat less so, at colleges with partial graduate programs than at strictly liberal arts colleges, as predicted by the theory. The exception is the positive coefficient for specialized institutions, which does not align with the commitment hypothesis; to the extent that faculty at specialized institutions are more homogeneous (and mobile) than their counterparts at liberal arts colleges, the commitment theory predicts less need at specialized institutions for the added security offered by divided democracy relative to unified democracy. Nevertheless, the marginal probability that joint action will be adopted (see column (3)) is significantly lower at specialized than liberal arts institutions, implying that, overall, specialized institutions remain less likely than other institutions to use either form of democratic governance.

Finally, to explore these relationships further, I reestimated the model including variables representing size and research prominence, the results of which are reported in columns (8) and (9). The main difference in the results is that the coefficient on UNIV in the joint action relative to administrator determination equation (column (8)) becomes insignificant. The coefficients on RESEARCH and FACSIZE, however, are significantly positive (at the 0.10 and $0.05 \%$ levels, respectively) in that column, again supporting the prediction that large, research-oriented institutions (i.e., universities) tend to prefer joint 
action over administrator determination. Other results are qualitatively unaffected.

To provide a sense of the magnitude of the predicted differences in governance arrangements, I report in Table VIII estimated probabilities using the results in columns (1) and (2) for the governance of tenure decisions for each of the sixteen possible combinations of institution type and affiliation. Starting in the top row, we see that administrators in specialized institutions are very likely to have sole authority over tenure decisions (probabilities in bold type) and that the probabilities of administrator determination decrease as we proceed down the table, whereas the probability that faculty will have exclusive authority over tenure decisions increases (though only slightly and hardly at all between liberal arts colleges and universities), with the more conspicuous increase occurring in the likelihood that tenure decisions will require joint action. The effects of institutional affiliation are of comparable magnitude: Authority for tenure decisions is substantially more likely to rest with administrators in public and Catholic institutions than in private ones. Comparing the extremes, administrators of specialized public institutions are estimated to have at least veto power over tenure decisions $99 \%$ of the time and full authority for tenure decisions with a probability of 0.81 , whereas faculty are predicted to have veto power over tenure at a majority of private research universities. Although the probability estimate for administrator determination is larger than that for joint action, the likelihood that tenure decisions will require the consent of both faculty and administrators is substantially higher at private research universities than at most other institutions.

\subsubsection{Alternative explanations}

The literature contains few positive theories of either political or academic governance that yield competing hypotheses. The most prominent economic theory of democracy, the preference aggregation or social choice approach associated with the work of Arrow (1963), has emphasized the efficiency and stability properties of voting rules. ${ }^{32}$ Among that

32. Shepsle (1993, p. 349) identifies a third perspective or "school of thought" on political governance-in addition to "status quo failure" (preference aggregation) and "gains from trade" (commitment) schools-that emphasizes economizing on information costs (see also Gilligan, 1993). Drawing on agency theory, this approach emphasizes the "benefits to colocating decision authority with the knowledge that is valuable to those decisions" (Jensen and Meckling, 1992, p. 253), and generally implies the allocation of authority to individuals who have "accumulated substantial prior expertise or competency" or for whom information is more important (Aghion and Tirole, 1997, p. 27; see also Baker et al., 1999). Although this theory has potential implications for the assignment of authority on specific decisions-for example, the assignment of hiring and promotion decisions to faculty, and budget decisions to administrators-it does not appear to offer clear predictions (separate from the commitment issues already discussed) for the variation in governance between institutions that is the focus of this paper. 
literature's best-known results is that, except where the decision space is unidimensional - that is, where voters care only about a single policy issue-any majority rule outcome is vulnerable to being overturned by another proposal (see McKelvey, 1979; Schofield, 1978; Plott, 1967). The prospect of instability and inefficiency, moreover, increase with the dimensions of the policy space (e.g., Greenberg, 1979; Schofield, 1986). Inasmuch as the number of issues (i.e., the dimensions of the decision space) increases with the heterogeneity of a population, social choice theory predicts a decrease in the performance, and hence attraction, of democratic decision making in organizations with more heterogeneous members. Although the greater incidence of joint action (divided democracy) relative to faculty determination (unified democracy) is consistent with the adoption of executive veto or bicameral legislatures as a structural remedy to the instability of majority rule (Hammond and Miller, 1987), the overall preference for democratic over autocratic governance in larger, more heterogeneous institutions exhibited in the data would seem to contradict the central implication of social choice theory. 33

Finally, it is sometimes argued that faculty participation in university governance simply reflects a faculty taste for control. If control is a normal good, faculty demand for control would increase with faculty earnings, implying more democratic governance at, for example, elite, research universities than lower-ranked teaching colleges, and at private than at public or religious institutions, as is observed in the data. Putting aside such questions as whether faculty actually have a taste for authority and how the shadow price of faculty time relates to faculty income and attributes, a taste-for-control explanation fails, however, to explain the observed preference for shared governance (joint action) over exclusive faculty determination in more elite, private and researchoriented institutions $\left(\Delta \beta_{d u}>0\right)$ indicated by the multinomial results. Taken as a whole, the set of predictions derived from the commitment theory (summarized in Table I) yields the best overall correspondence with the observed patterns of governance.

\section{CONCLUSION}

As a system of government, dictatorship has certain advantages. In contrast to decision makers in democratic systems, autocrats have the

33. The addition of veto points through executive veto or a bicameral legislature increases the likelihood that a voting equilibrium will exist but does not guarantee stability or efficiency of voting outcomes (Hammond and Miller, 1987). The concerns of formal social choice theory with heterogeneous voters and issues are also consistent with the general perception that size and heterogeneity reduce the appeal of democratic decision making by exacerbating conflict, protracting debate, and slowing responsiveness. See, for example, Benham and Keefer (1991, p. 709). 
authority to act unilaterally and decisively in response to unfolding events. The drawback of such discretion is the inability to commit to intervening non-opportunistically; unconstrained authority weakens the incentives of subordinates to invest in relationship-specific assets (Williamson, 1985) and to acquire information needed to make informed decisions (e.g., Aghion and Tirole, 1997) while increasing the return to efforts aimed at influencing its application (Milgrom and Roberts, 1990). The conundrum of executive authority is how, in the absence of effective third-party enforcement, an executive with unconstrained authority can commit to intervening only where doing so yields joint surpluses (Williamson, 1985, Ch. 6).

Increasingly, research on political institutions has come to view democratic governance as a response to just this problem. According to the theory, democracy enhances confidence in governmental policies (relative to autocracy) by providing a decision rule for evaluating the legitimacy of state actions that (i) is simple and readily verifiable (relative to evaluating the actions themselves) and (ii) expands the set of interests represented in those decisions. The larger the number of "veto points" created by the decision rule, the more stable policies are likely to be.

This paper has sought to shed light on the factors affecting the use of democratic governance by analyzing variations in the governance of colleges and universities. Two findings of the analysis stand out. The first is the greater tendency for democratic governance in general, and joint administrator-faculty determination in particular, in large, heterogeneous institutions. The second is the heavier reliance on administrator determination in public and Catholic institutions than in private colleges and universities. The first of these, in particular, challenges the conventional wisdom that size and heterogeneity seriously encumber democratic decision making (see, e.g., Hansmann, 1988, p. 294; Benham and Keefer, 1991). Though size and heterogeneity undoubtedly complicate democratic decision making, the relevant question in an institutional choice context is the effect of those attributes on the efficiency of democracy relative to alternative ways of governing transactions. The evidence on the governance of colleges and universities, at least, is consistent with the proposition that the benefits of democratic governance in facilitating coordination and deterring appropriation in communities of heterogeneous, immobile individuals outweigh the costs and inefficiencies of collective decision making in such settings.

The greater tendency toward autocratic governance in state and Catholic-affiliated institutions is also consistent with commitment considerations. Because democracy protects only enfranchised interests, democratic rule will tend to diminish the credibility of institutional commitments to external patrons on whom the institution or community 
may depend for resources or support. Where the interests of those who provide resources and of those who would control their disbursement diverge significantly, the supply of resources may depend on assigning authority to an autocrat-agent chosen and controlled by the donors.

Though the findings of this paper bear directly only on the governance of academic institutions, the hypotheses tested are extensions of more general theories of political and economic organization, and parallels in these broader areas are not difficult to find. The theory predicts, for instance, that divided democracy would be the superior form of government in large, heterogeneous countries (like the United States), while unified, parliamentary democracy, of the type found in many European countries, should dominate in smaller, more homogeneous nations. Parallels can also be found in the correlation between "extramural" interests and autocratic governance, as in the United States' support for dictatorships in countries thought crucial to preserving US interests during the Cold War or, more recently, Britain's noticeable ambivalence toward democracy in Hong Kong-until the colony's return to China became imminent and Britain's interests turned to preserving the status quo. For similar reasons, nations founded on strong non-individualistic ideologies (such as communism in the former Soviet Union or Maoist China) or fundamentalist religious beliefs (Iran and the Sudan, in recent times) should be more likely to be ruled by dictators. Countries may not choose their political institutions to fit their circumstances but, if the theory is correct, countries fortunate enough to have political institutions appropriate to their circumstances at a given point in their history should, ceteris paribus, outperform those whose political systems and economic and demographic conditions are misaligned (cf Qian and Weingast, 1996).

Finally, differences in the need for internal commitment also offer a plausible rationale for the relative infrequency of democratic governance in business organizations. On one side, the existence of an important class of external patrons-the firm's owners-on whom the organization is dependent for capital and whose interests-protection of investments against appropriation by insiders and overall maximization of long-run returns-may not align with the short-term interests of the firm's employees favors autocratic control. On the other is the potentially greater availability of alternative employment opportunities in commercial than academic settings-owing, in part, to the geographical dispersion of universities (Brennan and Tollison, 1980, p. 349)-which would tend to reduce the value of governance structures that enhance internal commitment: As Holmstrom (1999) puts it, "the very fact that workers can exit a firm at will and go to other firms, and that consumers and input suppliers and other trading partners can do likewise, limits 
the firm's ability to exploit these constituents [and] makes it feasible for the firm to go about its business of setting 'internal rules of the game' in a relatively unfettered fashion" (p. 90). However, even conventional business firms, he adds, "feel ... pressures to be democratic and nonpartial when exit is costly for its members": "Democracy is a costly governance procedure, but it appears to be the best one available when [as in the case of governments] exit is precluded" (id.). In fact, though we tend to view the internal organization of firms as monolithic, not all business entities are organized autocratically: Democratic decisionmaking is the predominant form of governance in commercial areas such as professional service partnerships; producer and consumer cooperatives (some of which are large enough to appear in the Fortune 500 list of industrial corporations (Hansmann, 1988)); and commodity and financial exchanges (Pirrong, 1999). The apparent success of a commitment orientation in explaining the internal governance of colleges and universities suggests a new direction for analyzing internal governance of other organizations.

\section{APPENDIX}

The following are the category definitions and instructions used in the survey published in the Report of the Survey Subcommittee of Committee T (1971), AAUP Bulletin, Spring, pp. 69-124:

Determination. Determination means that the faculty of an academic unit or its duly authorized representatives have final legislative or operational authority with respect to the policy or action, and any other technically required approvals or concurrences are only pro forma. Please consider actual practices followed.

Joint Action. Joint action means that formal agreement by both the faculty and other components of the institution is required for affirmative action or policy determination. Negative action can be accomplished by a veto by any component. The separate components need not act simultaneously but should act within a reasonable time interval. In no case should the interval be longer than an academic year.

Consultation. Consultation means that there is a formal procedure or established practice which provides a means for the faculty (as a whole or through authorized representatives) to present its judgment in the form of a 
recommendation, vote or other expression sufficiently explicit to record the position or positions taken by the faculty. This explicit expression of faculty judgment must take place in time to affect the decision to be made. Initiative for the expression of faculty judgment may come from the faculty, the administration, or the board.

Discussion. Discussion means there is only an informal expression of opinion from the faculty or from individual faculty members; or that there is formally expressed opinion only from administratively selected committees.

None. None means that there is no faculty participation.

In ascertaining the form of a faculty participation in a given academic unit (college, school, department) in a given decision-making process, find that instance in which the level of participation was least. The form of this instance is the form of participation for that academic unit in the decision-making process. In particular, all specific instances in the time period to be covered for the specific question, through all decision levels without a single exception, must be at least at the minimum participation level indicated for that academic unit [emphasis is the original].

\section{REFERENCES}

Aghion, P. and J. Tirole, 1997, "Formal and Real Authority in Organization," Journal of Political Economy, 105, 1-29.

Allen, D.W., 1995, “Order in the Church: A Property Rights Approach," Journal of Economic Behavior and Organization, 27, 97-117.

Alt, J.E. and K.A. Shepsle (ed.), 1990, Perspectives on Positive Political Economy, Cambridge, UK: Cambridge University Press.

Arrow, K., 1963 [1951], Social Choice and Individual Values, 2nd ed., New York: Wiley.

Baker, G., R. Gibbons, and K.J. Murphy, 1999, "Informal Authority in Organizations," Journal of Law, Economics, and Organization, 15, 56-73.

Benham, L. and P. Keefer, 1991, "Voting in Firms: The Role of Agenda Control, Size and Voter Homogeneity," Economic Inquiry, 29, 706-719.

Bernheim, B.D. and M.D. Whinston, 1998: "Incomplete Contracts and Strategic Ambiguity," American Economic Review, 88, 902-932.

Besse, R.M., 1973, "A Comparison of the University with the Corporation," in James A. Perkins, ed., The University as an Organization, New York: McGraw Hill, 107-120.

Bordignon, M. and E. Minelli, 1998, "Rules Transparency and Political Accountability," IGIER Universita Bocconi Working Paper No. 147 (http:/ / ssrn.com/abstract=156268).

— and - 2000, "Efficienza delle regole e responsabilizzazione dei politici (Efficiency of Rules and Accountability of Politicians)," Politica Economica, 16, 285-303.

Brennan, H.G. and R.D. Tollison, 1980, "Rent Seeking in Academia," in J.M. Buchanan, R.D. Tollison, and G. Tullock, eds., Toward a Theory of the Rent-Seeking Society, College Station, TX: Texas A\&M University Press, 344-358. 
Buchanan, J.M. and G. Tullock, 1962, The Calculus of Consent, Ann Arbor, MI: University of Michigan Press.

Carmichael, H.L., 1988, “Incentives in Academics: Why Is There Tenure?" Journal of Political Economy, 96, 453-472.

Carnegie Commission on Higher Education, 1973, A Classification of Institutions of Higher Education, Berkeley, CA.

Coase, R.H., 1937, "The Nature of the Firm," Economica N.S., 4, 386-405.

Crocker, K.J., and S.E. Masten, 1991, “Pretia Ex Machina? Prices and Process in Long-Term Contracts," Journal of Law and Economics, 34, 69-99.

de Russy, C., 1996, "Public Universities Need Rigorous Oversight by 'Activist' Trustees," Chronicle of Higher Education, 11, B3-B4.

Duryea, E.D., 1973, “Evolution of University Organization," in James A. Perkins, ed., The University as an Organization, New York: McGraw Hill, 15-37.

Ehrenberg, R., H. Kaspar, and D. Rees, 1991, “Faculty Turnover at American Colleges and Universities: Analyses of AAUP Data," Economics of Education Review, 10, 99-110.

Fiorina, M.P., 1996, Divided Government, 2nd ed., Boston: Allyn and Bacon.

Frant, H., 1993, "Rules and Governance in the Public Sector: The Case of Civil Service," American Journal of Political Science, 4, 990-1007.

Gibbons, R., 1987, "Piece-Rate Incentive Schemes," Journal of Labor Economics, 5, 413-429.

— 1998, "Incentives in Organizations," Journal of Economic Perspectives, 12, 115-132.

Gilligan, T.W., 1993, "Information and the Allocation of Legislative Authority," Journal of Institutional and Theoretical Economics, 149, 321-341.

Goldberg, V.P., 1976, "Regulation and Administered Contracts," Bell Journal of Economics, $7,425-448$.

Goldin, C. and L.F. Katz, 1999, "The Shaping of Higher Education: The Formative Years in the United States, 1890 to 1940," Journal of Economic Perspectives, 13, 37-62.

Greenberg, J., 1979, "Consistent Majority Rules over Compact Sets of Alternatives," Econometrica, 47, 627-636.

Greene, W.H., 1995, Limdep, Version 7.0, Bellport, NY: Econometric Software Inc.

Grief, A., 1993, "Contract Enforceability and Economic Institutions in Early Trade: The Maghribi Traders' Coalition," American Economic Review, 83, 525-548.

Gross, E. and P.V. Grambsch, 1974, Changes In University Organization, 1964-1971, New York: McGraw-Hill.

Grossman, S. and O. Hart, 1986, "The Costs and Benefits of Ownership: A Theory of Vertical and Lateral Integration, "Journal of Political Economy, 94, 691-719.

Hammond, T.H. and G.J. Miller, 1987, "The Core of the Constitution," American Political Science Review, 81, 1155-1174.

Hansmann, H., 1980, “The Role of Nonprofit Enterprise," Yale Law Review, 89, 835-899.

— 1988, "The Ownership of the Firm," Journal of Law, Economics, and Organization, 4, 267-304.

Hardin, R., 1989, “Why a Constitution?” in B. Grofman and D. Wittman, eds., The Federalist Papers and the New Institutionalism, New York: Agathon Press, 100-120.

Hollinger, D.A., 2001, "Faculty Governance, The University of California, and the Future of Academe," Academe, 87, 30-33.

Holmstrom, B., 1999, "The Firm as a Subeconomy," Journal of Law, Economics, and Organization, 15, 74-102.

Holmstrom, B. and P. Milgrom, 1991, “Multitask Principal-Agent Analyses: Incentive Contracts, Asset Ownership and Job Design," Journal of Law, Economics, and Organization, $7,24-52$.

— and — 1994, "The Firm as an Incentive System," American Economic Review, 84, 972-991. 
Jensen, M.C. and W.H. Meckling, 1992, "Specific and General Knowledge, and Organizational Structure," in L. Werin and H. Wijkander, eds., Contract Economics, Cambridge, MA: Basil Blackwell Ltd., 251-274.

Kandori, M., 1992a, "Social Norms and Community Enforcement," Review of Economic Studies, 59, 63-80.

_ $1992 \mathrm{~b}$, "Repeated Games Played by Overlapping Generations of Players," Review of Economic Studies, 59, 81-92.

Klein, B., R.A. Crawford, and A.A. Alchian, 1978, "Vertical Integration, Appropriable Rents, and the Competitive Contracting Process," Journal of Law and Economics, 21, 297-326.

Krehbiel, K., 1991, Information and Legislative Organization, Ann Arbor, MI: University of Michigan Press.

— 1996, "Institutional and Partisan Sources of Gridlock: A Theory of Divided and Unified Government," Journal of Theoretical Politics, 8, 7-39.

Maser, S.M., 1998, "Constitutions as Relational Contracts: Explaining Procedural Safeguards in Municipal Charters," Journal of Public Administration, 8, 527-564.

Masten, S.E., 1995, “Old School Ties: Financial Aid Coordination and the Governance of Higher Education," Journal of Economic Behavior and Organization, 28, 23-47.

— 2006, "The Evolution of University Governance: A Comparative Institutional Analysis," Working paper.

McCormick, R.E. and R.E. Meiners, 1988, “University Governance: A Property Rights Perspective," Journal of Law and Economics, 31, 423-442.

McGuire, M.C. and M. Olson Jr., 1996, "The Economics of Autocracy and Majority Rule: The Invisible Hand and the Use of Force," Journal of Economic Literature, 34, 72-96.

McKelvey, R.D., 1976, "Intransitivities in Multidemensional Voting Models and Some Implications for Agenda Control," Journal of Economic Theory, 12, 472-482.

—_ 1979, "General Conditions for Global Intransitivity in Formal Voting Models," Econometrica, 5, 1085-1112.

McKenzie, R.B., 1979, “The Economic Basis of Departmental Discord in Academe," Social Science Quarterly, 59, 653-654.

_ - 1996, "In Defense of Academic Tenure," Journal of Institutional and Theoretical Economics, 152, 325-341.

Mercer, J., 1995, “Yale Returns \$20-Million Gift," Chronicle of Higher Education, 28 (March 24), A36.

Milgrom, P. and J. Roberts, 1990, “Bargaining Costs, Influence Costs, and the Organization of Economic Activity," in J. Alt and K. Shepsle, eds., Perspectives on Positive Political Economy, Cambridge, UK: Cambridge University Press, 57-89.

— and - 1992, Economics, Organization \& Management, Englewood Cliffs, N.J.: Prentice-Hall.

Miller, G.J., 1997, “The Impact of Economics on Contemporary Political Science," Journal of Economic Literature, 35, 1173-1204.

Miller, G.J. and T.H. Hammond, 1989, "Stability and Efficiency in a Separation-of-Powers Constitutional System," in B. Grofman and D. Wittman, eds., The Federalist Papers and the New Institutionalism, New York: Agathon Press, 85-99.

Moe, T.M. and M. Caldwell, 1994, "The Institutional Foundations of Democratic Government: A Comparison of Presidential and Parliamentary Systems," Journal of Institutional and Theoretical Economics, 150, 171-195.

Munroe, J.P., 1899, “Applied Science and the University," Technology Review, 1, 153-169.

North, D.C. and B.R. Weingast, 1989, "Constitutions and Credible Commitments: The Evolution of the Institutions of Public Choice in 17th Century England," Journal of Economic History, 49, 803-832. 
Patashnik, E.M., 1996, "The Contractual Nature of Budgeting: A Transaction Cost Perspective on the Design of Budgeting Institutions," Policy Sciences, 29, 189-212.

Pfiffner, J.P., 1991, “Divided Government and the Problem of Governance," in J.A. Thurber, ed., Divided Democracy: Cooperation and Conflict Between the President and Congress, Washington, DC: Congressional Quarterly Press.

Pirrong, S.C., 1999, "The Organization of Financial Exchange Markets: Theory and Evidence," Journal of Financial Markets, 2, 329-357.

Plott, C.R., 1967, “A Notion of Equilibrium and Its Possibility under Majority Rule," American Economic Review, 57, 787-806.

Qian, Y. and B.R. Weingast, 1996, "China's Transition to Markets: Market-Preserving Federalism," Journal of Policy Reform, 1, 149-186.

Ransom, M., 1993, "Seniority and Monopsony in the Academic Labor Market," American Economic Review, 221-233.

Reid, J., 1998, “The Danger of Living Under Elected Dictatorship," The Herald (Glasgow), March 25, 19.

Report of the Survey Subcommittee of Committee T, 1971, AAUP Bulletin, Spring, 69-124.

Schofield, N., 1978, "Instability of Simple Dynamic Games," Review of Economic Studies, $45,575-594$.

_ 1986 , "Existence of a 'Structurally Stable' Equilibrium for a Non-Collegial Voting Rule," Public Choice, 51, 267-284.

Schuster, J.H., J.H. Schuster, D.G. Smith, K.C. Sund, and M.M. Yamada, 1994, Strategic Governance, Phoenix, AZ: Oryx Press.

Shelanski, H.A. and P.G. Klein, 1995, "Empirical Research in Transaction Cost Economics," Journal of Law, Economics, and Organization, 11, 335-361.

Shepsle, K.A., 1993, "Political Institutions and the New Institutional Economics: Comment," Journal of Institutional and Theoretical Economics, 149, 347-350.

Simon, H.A., 1951, "A Formal Theory of the Employment Relationship," Econometrica, 19, 293-305.

Stata Corp., 1999, User's Guide, College Station, TX: Stata Press.

Sundquist, J.L., 1986, Constitutional Reform and Effective Government, Washington, DC: Brookings Institution.

Tiebout, C., 1956, "A Pure Theory of Local Public Expenditures," Journal of Political Economy, 64, 416-424.

U.S. Office of Education, National Center for Educational Statistics, 1971.

Veysey, L.R., 1965, The Emergence of the American University, Chicago: The University of Chicago Press.

Walsh, S., 2002, “On the Firing Line," The Chronicle of Higher Education, May 3, A10.

Weingast, B.R., 1993, “Constitutions as Governance Structures: The Political Foundations of Secure Markets," Journal of Institutional and Theoretical Economics, 149, 286-311.

— 1995, "The Economics Role of Political Institutions: Market-Preserving Federalism and Economic Development," Journal of Law, Economics, and Organization, 11, 1-31.

— and W.J. Marshall, 1988, "The Industrial Organization of Congress; or, Why Legislatures, Like Firms, Are Not Organized As Markets," Journal of Political Economy, 96, 132-163.

Williamson, O.E., 1975, Markets and Hierarchies, New York: The Free Press.

- 1985. The Economics Institutions of Capitalism, New York: The Free Press. 